\title{
ESCENAS, PROTESTA Y COMUNIDAD. CINE Y NARRATIVA EN CHILE Y ARGENTINA (2001-2015)
}

\author{
Scenes, Protest and Community. \\ Cinema and Narrative in Chile and Argentina (2001-2015)
}

Luis Valenzuela Prado*

\section{RESUMEN}

Este artículo propone una lectura de la performatividad de los cuerpos en las marchas o protestas políticas, lo que será analizado a partir de un corpus de novelas y películas chilenas y argentinas (2001-2015). Durante los procesos de posdictadura y en economías neoliberales, se erigen ciertas retóricas colectivas -con estéticas y contextos diferentes- en las que los cuerpos se desmarcan o asumen una escena pública y social de la comunidad/multitud. Así, se revisan conceptos como los de coreografía, performance política y realización performativa, los cuales permiten analizar el gesto "político" de intervenir o desestimar la escena de protesta.

Palabras clave: performatividad, multitud, espectáculo, cine y literatura chilena y argentina.

\footnotetext{
${ }^{1}$ Este artículo es resultado del proyecto FONDECYT de Iniciación N 11140613 "Retóricas del espectáculo. Articulaciones entre la novela y el cine en Chile y Argentina. 2001-2015”, que dirigí como Investigador responsable.

* Licenciatura en Letras, Facultad de Educación y Ciencias Sociales, Universidad Andres Bello. Santiago, Chile. Correo electrónico: luis.valenzuela.p@unab.cl
}

Recibido el 12 de noviembre de 2017. Aceptado el 13 de abril de 2018. 


\begin{abstract}
This article proposes an interpretation to the configuration of bodies in their performativity in political marches and/or protests. This performativity will be analyzed from a corpus of Chilean and Argentine novels and films (2001-2015), from which it is argued that, through different aesthetics and contexts, certain collective rethorics arise, in which bodies dissociate from or take on the public and social scene of the community/crowd, inserted in postdictatorial processes, anchored in neoliberal economies. It is in this respect that concepts such as choreography, political performance and performative realization are revised, allowing the analysis of the "political" gesture of intervention or dismissal the protest scene.
\end{abstract}

Keywords: Performativity, crowd, spectacle, chilean and argentine cinema and literature.

\title{
1. Introducción. La crisis y la calle, una propuesta de escena
}

Partamos de la base de dos escenas: la primera, la crisis económica argentina del año $2001 \mathrm{y}$, la segunda, las manifestaciones estudiantiles en Chile durante los años 2006 y 2011. Los acontecimientos de la noche del 19 de diciembre de 2001 en Argentina, las protestas, saqueos y cacerolazos, "no llegaron sin señales", son el resultado de un proceso de fracasos económicos y políticos, una década de políticas neoliberales (Schwartz, 2017, p. 20)². En el contexto de la renuncia de Fernando de la Rúa (1999-2001) y de que le siguieran cinco presidentes que asumen y dimiten en el período de dos semanas, el "lema '¡Que se vayan todos!', gritado en las calles, pintado en graffitis, impreso en banderas, expresó la crisis de confianza y legitimidad en los líderes elegidos y en todo el sistema político representativo" (Schwartz, 2017, p. 20). Respecto de la segunda escena, el movimiento estudiantil en Chile convoca y junta, según Rubí Carreño (2013), "subjetividades colectivas que se encontraban fracturadas. Jóvenes, trabajadores y artistas volvieron masivamente a la calle por una educación gratuita y por el fin a lo que ellos llaman 'lucro' y que se define como el interés de la ganancia por sobre cualquier otro tipo de consideración" (Av. Independencia, p. 220). Este movimiento carga con una estela histórica, tal

\footnotetext{
2 "El gobierno de Menem -en contra de la plataforma del partido Peronista- implementó políticas conservadoras neoliberales como la privatización de los recursos naturales y la infraestructura. Cuando el Fondo Monetario Internacional dejó de aprobar préstamos a Argentina, la economía colapsó" (Schwartz, 2017).
} 
vez "aspiraciones de las generaciones militantes de finales de los sesenta y de principios de los setenta: la imaginación al poder, las reformas universitarias de Francia y de Chile, el fin de la inequidad y desigualdad social..." ( $A v$. Independencia, p. 220). Ambos hitos convocan a la gente, a grupos organizados, a ocupar las calles como una puesta en escena política que critica y llama la atención de las autoridades y de la sociedad. Los piqueteros y los movimientos sociales, surgidos con la irrupción de la crisis argentina del 2001 -mantenidos durante los gobiernos posteriores- obedecen a diversas lógicas de crítica al Estado y de operativos por parte de este, mientras que los estudiantes en Chile establecen una crítica directa al aparato estatal. En ese contexto, el despliegue de la multitud/comunidad, vigilado por la institucionalidad policial, se erige como un enunciado colectivo de cuerpos en escena.

La narrativa y el cine en Chile y Argentina comparten ciertas semejanzas en sus contextos políticos y culturales, presentando convergencias en la forma en que estos son representados y problematizados. Durante las últimas décadas experimentan violentas dictaduras, las cuales fueron seguidas de procesos de transición y posdictadura, de cambios económicos y tecnológicos, de instancias de globalización y de predominio del mercado, pero sobre todo de una forma espectacularizada de entablar relaciones sociales y personales. Tanto en la novela como en el cine de los primeros tres lustros del siglo XXI se aprecia cierta materialidad descrita y visualizada de escenas cotidianas, cinematográficas, teatralizadas, performáticas. Novelas y películas marcadas por una heterogeneidad de autores que desembocan en problemas y representaciones vinculantes. En este contexto, surge una retórica performática de la colectividad que se manifiesta en marchas y protestas políticas, las cuales son analizadas en este artículo ${ }^{3}$. Es pertinente, entonces, leer algunos hitos que funcionan como telón de fondo de esta retórica: primero, se trata de escenas contemporáneas en ambos países - desde el año 2000 a la fecha- que muestran una agenda heterogénea respecto de las matrices culturales que rodean a estas convocatorias, que pueden surgir de demandas sociales concretas o ser manifestaciones espontáneas. Segundo, en ambos casos el neoliberalismo opera como sustento político económico, en Chile desde la dictadura de Pinochet

\footnotetext{
${ }^{3}$ Este artículo forma parte de los resultados de una investigación que propone cuatro ejes de análisis en torno a un corpus de novelas y películas chilenas y argentinas. El primero, analiza imágenes y escenas de la memoria y de la historia; el segundo, del cual surge este artículo, analiza diversas comunidades, políticas y religiosas, leídas desde la performatividad de los cuerpos y la comunidad. El tercero, analiza la representación del cuerpo como mercancía y su reverso de cuerpo muerto desespectacularizado. El cuarto, analiza diversos dispositivos tecnológicos de la intimidad, que vinculan escritura, sujeto y dispositivo.
} 
y en Argentina desde el período de posdictadura a partir de los gobiernos de Menem. Tercero, la recuperación de la matriz histórica de la marcha y del movimiento social. En esa línea, se propone una hipótesis que considera estas retóricas performáticas -cuerpos que se desmarcan o asumen la escena en cuestión- como gestos que reaccionan o se alinean con los procesos políticos de posdictadura neoliberal. En esa línea, el objetivo general busca articular una lectura en torno a cómo la comunidad/multitud se vincula y desvincula performáticamente de la escena de la marcha. Desde ahí se traza un lineamiento metodológico transversal que permite relacionar cine y literatura, en tanto formas que, por un lado, articulan relatos, y por otro, convergen en una idea de escena desde la imagen cinematográfica que exacerba la idea de escena y una idea de literatura que transita hacia una visualidad. En ese sentido, el análisis de un corpus interdisciplinar permite complementar y comprender ciertos puentes y tránsitos críticos ${ }^{4}$.

\section{Aristas teóricas del problema: performance, comunidad y desmarque}

Las marchas y protestas se enmarcan en un disentir político colectivo. Según Mario Garcés (2012) los movimientos sociales y los cambios políticos se vinculan desde fines del siglo XIX con el movimiento obrero, pero desde la década de los sesenta del siglo XX esa asociación comienza a romperse y relacionarse con otras manifestaciones colectivas como la de los estudiantes de mayo del 68 francés o los movimientos contra la guerra de Vietnam. Luego, en América Latina, "en medio de las dictaduras" (p. 9), aparecen otros "actores colectivos" (p. 9): movimientos de derechos humanos, de mujeres, juveniles o ecologistas (p. 9), distinguiéndose entre "movimientos sociales tradicionales" -obreros y campesinos- y los "nuevos movimientos sociales" (p. 9). Sin embargo, el horizonte de "movimiento social" se mantiene siempre como "una acción colectiva", constituida "desde la sociedad civil o desde lo social", para visibilizar el "malestar y diversas demandas al Estado y sus instituciones y representantes" (10) Surge, entonces, las preguntas: ¿quiénes son los que marchan? y ¿cómo se agrupan o desagrupan?

\footnotetext{
${ }^{4}$ Para un análisis interdisciplinar de un corpus chileno-argentino, resulta pertinente revisar el trabajo de Wolfgang Bongers (2017). Para trabajos que atienden narrativas recientes se sugiere revisar, entre otros, en el caso chileno, Patricia Espinosa, Lorena Amaro, Macarena Areco, María Teresa Johansen; y para el caso argentino, Elsa Drucaroff, Maximiliano Crespi y Beatriz Sarlo. En cuanto a las cinematografías recientes, en el caso chileno, revisar Pablo Corro e Iván Pinto; y para el caso argentino, revisar Gonzalo Aguilar, Pablo Piedras, Jens Andermann.
} 
La definición de comunidad ${ }^{5}$ o del colectivo de cuerpos se erige desde diferentes matices. Aguilar (2016) aborda la relación entre imagen cinematográfica y los "muchos" desde tres dimensiones: 1) Plantea la pregunta de cómo nombrarlos: “¿Masa, turba, multitud, comunidad, pandilla, público, pueblo?" (Más allá, p. 182) Al concebir los cuerpos desde la idea de lo coreográfico, las direcciones del movimiento son orgánicas, de manera que se pueden mirar estas películas como si fueran musicales; 3) La dimensión del "enunciado mayestático, que combina la imagen con el habla" (Más allá, p. $183)^{6}$. Aguilar entiende la idea de comunidad como coreografía de cuerpos, cuya enunciación colectiva articula imagen y habla. Ossa (2013), por su parte, habla de comunidad y no de nación, tampoco de pueblo, sociedad, ni Estado, pues el concepto de comunidad le permite al cine abordar ciertos sujetos invisibles. En otra línea, Tabarowsky (2014) establece que estar al margen de la comunidad es descreer de ella (p. 29). Otra categoría pertinente es la de pueblo, para la cual Butler analiza el enunciado "nosotros, el pueblo" (p. 41), y señala que en él subyace una tensión con una vulnerabilidad frente al poder o las instituciones. En ese sentido, Didi-Huberman (2012), cuando piensa "imágenes y pueblos", entiende que han sido "reducidos las primeras a puros procesos de sometimiento y los segundos a puros cuerpos sometidos" (p. 78). Negri (2008) articula una tercera categoría relevante, que es la de multitud -"multiplicidad de singularidades" (p. 65)- y que pone en cuestión la de pueblo. Multitud sería "una unidad artificial que necesita el Estado moderno como base de la ficción de la legitimación", es decir, "masa", en tanto "base del modo capitalista de producción [en sí,] una unidad indiferenciada" (p. 65).

Ahora, surgen dos nuevas preguntas para pensar el problema: ¿qué sucede con el disentir en relación con la marcha? o ¿qué dicen los cuerpos cuando marchan? Todo recorrido de un cuerpo es una enunciación. De Certeau (2000) señala que la historia comienza a ras de suelo, con los pasos que se escriben al andar. Los cuerpos en tránsito -vinculante o desvinculante desde o hacia el centro colectivo- operan como una forma de retórica performática que en su movimiento enuncia. "No importa la clase social de la que se provenga", sostiene Aguilar, "hay que saber moverse en la sociedad del espectáculo" (Más allá, 2016, p. 250). Desde ahí, es posible analizar el gesto político que implica la intervención de la escena pública y en cuyo relato se encuentra latente una

\footnotetext{
${ }_{5}^{5}$ Para profundizar, ver Jean-Luc Nancy, La comunidad inconfesable; Roberto Esposito, Comunidad, inmunidad y biopolítica; Giorgio Agamben, La comunidad que viene, entre otros.

${ }^{6}$ En lingüística el término se refiere al plural que utiliza el rey y que incluye a todos los gobernados. Esto se da de forma recurrente en Shakespeare.
} 
retórica del espectáculo que supone saber moverse o no en dicha escena. Para leer y comprender el movimiento de esos cuerpos, cobra relevancia el concepto de performance. Para Taylor (2015), en América Latina el término no conoce equivalente en español ni en portugués (p. 47), por cierto, incluye otros "como teatralidad, espectáculo, acción, representación" (p. 47).

La performance, continúa Taylor, funciona "como práctica corporalizada y episteme", descentra "el papel histórico de la escritura introducido por la conquista" (p. 52). Los cuerpos -en tanto textos-"también trasmiten información, memoria, identidad, emoción y mucho más..." (p. 18), es decir, constituyen "actos de transferencia", que "tienen sus propios códigos, su propia lógica. Sus formas propias de autoproducirse". Tanto performance como las "estéticas de la vida cotidiana", expone Taylor, "varían de comunidad en comunidad, al reflejar especificidades culturales e históricas..." (p. 35). Tales variaciones implican "maneras de hacer" que modifican y especifican, desde una lógica ranceriana, "las formas de hacer y en sus relaciones con las maneras de ser y las formas de visibilidad" (El reparto de lo sensible estética y política, 2014, p. 20) en la comunidad, desembocando en las diferentes formas de articulación de la marcha y la protesta analizada. Resulta pertinente, entonces, preguntarse sobre los matices que ocupan los cuerpos en la marcha como relato corporal.

Pensemos la organización de los cuerpos como una enunciación, en tanto que en la acción de agruparse, las personas "crean un modo de hablar colectivo y demandan un cambio político o la disolución del Gobierno" (Butler, 2014, p. 41). Respecto del enunciado "nosotros, el pueblo", Butler sostiene que, por una parte, "busca dar lugar a la pluralidad social que nombra", no la describe, la produce como "pluralidad social que enuncia" (p. 44); y, por otra, el enunciado no explica "quién es el pueblo pero marca la forma de autoconstrucción. . ." (p. 46) que se encamina hacia una configuración. De ahí que, toda declaración implica una serie de actos de habla o de realizaciones performativas (46), es decir, la reunión de cuerpos sugiere la soberanía popular como un ejercicio de los cuerpos. No se puede hablar de cuerpos sin un contexto: "complejos sistemas de interdependencia social que constituyen sus condiciones de asistencia; ningún cuerpo sobrevive, y mucho menos florece, sin estas condiciones" (Butler, 2014, p. 54). En rigor, el "cuerpo no es solo una entidad discreta con límites fijos", sino una serie de relaciones con cultura comida, vivienda, sexualidad, movilidad, audibilidad y visualidad (p. 55). Entonces, el horizonte final de la política no es solo salir en grupo a la calle, es importante atraer y llamar la atención del mundo, pues mostrarse implica "ser desafiante... un modo de crear un nuevo cuerpo político" (Butler, 2014, p. 59). Lo performático -como gesto político- desafía en tanto corporalidad y complejidad cultural y política. Así, 
los cuerpos, desde el lugar del reparto ranceriano, al desafiar, cuestionan ese reparto y las operaciones desde y hacia este.

La lectura performática implica una lectura crítica que lee el movimiento de los cuerpos, independiente de las consignas que buscan levantar quienes se manifiestan. En esa lógica, Olga Grau (2000) analiza la escena del encapuchado, quien tapa y tacha su rostro, haciendo desaparecer su "cuerpo identitario" (p. 200). La entrada a escena es nominada como "acción callejera", "salir", "ir a la pelea", "salir a dejar la cola" y también "hay hueveo" (p. 202). Grau se pregunta si estos actos constituyen una "suerte de performance política, la performance del no olvido" (p. 202), actos en los que "no hay discurso, pero sí relato", la "escenificación de una habla catártica", la "teatralización de un conflicto", una "geometría de los cuerpos que interactúan", "una estética política" (p. 202). Para Aguilar (2010), las coreografías son una puesta en escena del cuerpo, una exhibición de la teatralidad de la vida y del poder del cine para entregar performances más poderosas ${ }^{7}$.

Una idea central de este artículo es reflexionar acerca de las vinculaciones y desvinculaciones, sean colectivas respecto de un estado político, o subjetivas en relación con la comunidad. La idea ranceriana de desmarque ${ }^{8}$ erige el "reparto de lo sensible" como un "sistema de evidencias sensibles" que permite ver la existencia de un "común y los recortes que definen sus lugares y partes respectivas" (El reparto de lo sensible estética y política, 2010, p. 19). En ese sentido, la política se refiere "a lo que vemos y a lo que podemos decir, a quien tiene la competencia para ver y la cualidad para decir, a las propiedades de los espacios y los posibles del tiempo" (20). Entonces, serán los sujetos o el colectivo que se enfrenta a la marcha, quienes puedan enmarcarse o desenmarcarse del reparto asignado, asumirán o cuestionarán sus propias posibilidades de estar o no estar en la escena.

\footnotetext{
${ }^{7}$ Literalmente, la performance es una intervención artística de un espacio social y cultural, una "irrupción gestual, imprevista, no explícita, desafiante que escapa -o trata de escapar- a cualquier esfuerzo definitorio", al exhibir "la incomodidad ante los sistemas de sentido o convenciones dominantes" (Domínguez, 124).

${ }^{8}$ Que se expresan en el desacuerdo político en El desacuerdo. Política y filosofía; en la desvinculación de las imágenes con su referente en El destino de las imágenes -que Alejandra Castillo lee como gesto performativo: "La imagen, entonces, como falla y alteración, como apertura y performance" (p. 59)-, en la búsqueda de un espectador activo en El espectador emancipado, en el desmarque del proletario que luego de su larga jornada laboral dedica el poco tiempo libre para leer, en La noche de los proletarios.
} 


\section{Análisis. Vinculaciones y desvinculaciones}

\subsection{Comunidad y multitud uniforme}

La representación de la comunidad y la protesta ofrece una gama de representaciones, sobre todo en el documental chileno y argentino. No obstante, resulta un gesto inabordable analizar todo ese material que da cuenta de la multitud histórica como puesta en escena de un cuerpo político9. Revisemos dos ejemplos pertinentes: La dignidad de los nadies de Fernando Pino Solanas (2005) y La ciudad de los fotógrafos de Sebastián Moreno (2006). El primero, muestra ecos del cine político de los años sesenta, anclado en la noción de pueblo cuyo mensaje político y social es explícito. El segundo, presenta la nostalgia por la lucha política organizada, una forma de rearticular -mediante la imagen cinematográfica- la imagen fotográfica que registra la marcha política en contra de la dictadura de Pinochet. En ambos caso, los protagonistas asumen las condiciones del relato colectivo.

La protesta, en general, recurre a intervenciones artísticas o performáticas, de arte político. La protesta en formato de performance política aparece en La oscura memoria de las armas de Ramón Díaz Eterovic, es una escena de transición que evoca episodios de la dictadura. En esta, el ejercicio de no olvido encuentra eco en la manifestación pública y colectiva llamada funa -en Argentina, la llaman escrache ${ }^{10}$, que busca justicia popular y "transformar la memoria en acción" como modo novedoso "de denunciar la impunidad" (Díaz Eterovic, 2008, p. 57). Para Grau, la funa funciona como performance política, la "performance del no olvido", una "acción callejera" que reconoce "un argumento político hecho gesto (en contra de...) corporeizado", acción que tiene algo de protesta, enfrentamiento y agitación (pp. 202-3). Uno de los personajes de la novela, afirma que "Nos apoyamos en el arte para denunciar a los criminales y generar conciencia de masas" (Díaz Eterovic, 2008, p. 57), por lo que el arte se sustenta en una suerte de espectacularización que interviene la rutina citadina. La ciudad neoliberal de

\footnotetext{
${ }^{9}$ Resulta abundante el material documental sobre la multitud, en registro político, tanto en Chile como en Argentina. Algunos ejemplos para el caso chileno son: Actores secundarios (2004) de Pachi Bustos y Jorge Leiva; El vals de los inútiles (2013) de Edison Cajas; La revolución de los pingüinos (2008) de Jaime Díaz; y ANDHA (2014) de Enrique Veloso. Por su parte, para el caso argentino, resulta pertinente revisar: Panzas (2001) de Laura Bondarevsky; Piqueteras (2002) de Malena Bystrowicz, Verónica Mastrosimone y Miguel Magud; y La crisis causó 2 nuevas muertes (2006) de Patricio Escobar y Damián Finvarb, entre otros.

${ }^{10}$ Es la que aparece en el documental Panzas (2001) de Laura Bondarevsky.
} 
la novela ofrece una ruta de consumo, a la que se enfrenta el contrarrelato de la manifestación pública como oposición al silencio sistémico. En ese sentido, la funa es articulada: "No es la protesta de antaño, sino de una ciudad actual, minoritaria, sin nostalgia, que mira el presente para no olvidarlo" (Valenzuela, 2017, p. 151). En rigor, la funa rompe con la cotidianidad del sujeto cuestionado, que es sometido al ejercicio performático para enunciar su infamia desde una voz colectiva, desde una enunciación mayestática, es decir, en la línea de Aguilar, representaría el grito colectivo en escena. Tanto en los dos documentales como en la novela, el relato colectivo enuncia una crítica que avanza en el mismo sentido que la de los protagonistas, sus cuerpos escenifican y enuncian el clamor del pueblo en cuestión.

\subsection{Comunidad y multitud incómoda}

Una escena citadina, anclada en los años ochenta en Chile, es la que protagoniza la Loca del Frente en Tengo miedo torero de Pedro Lemebel (2008). En esta, el sujeto homosexual rompe la fila de la multitud, traspasa la línea de frontera marcada por la policía y los límites del reparto. En un momento de la novela, que ocurre en el espacio cerrado de la protagonista, se ve a la Loca en pleno centro de Santiago, llevando un encargo de Carlos a un hombre. En calle Ahumada, se cruza con la multitud, una "muchedumbre" que arranca gritando: "Pinochet-CNI-Asesinos del país" (p. 125), momento en que corren y lanzan panfletos que "nevaban el desconcierto de la Loca, estática en medio de la trifulca": "Y-va-a-caer, y-va-a-caer, paco-culiao-cafiche-del-estado. Cuidado que vienen por la Alameda. Corra que parecen perros apaleando gente" (p. 125). En medio del alboroto, la Loca enfrenta la muralla, camina "directamente al encuentro de la brutalidad policial. ¿Me deja pasar?, le dijo al primer uniformado que tuvo en frente. $\mathrm{Y}$ el paco sorprendido ante el descaro de esta pajarraca real, titubeó al empuñar la luma, al alzar la luma para quebrar esa porcelana altanera" (p. 125). La Loca insiste y rompe el acorazado muro. La muchedumbre/multitud se articula en un ir y venir con la policía, un saber moverse coreográficamente en tiempos de violencia. En ese sentido, La Loca se desmarca y asume un ritmo propio. Una entrada y salida de escena.

Una multitud, también desbordada, pero ahora previo a la crisis argentina del año 2001, es la que anticipa las escenas finales de la película Nueve reinas de Fabián Bielinsky (2000) - estrenada un año antes de la crisis-. Una multitud, en su cúmulo de singularidades, se agolpa espontáneamente en el banco, sin orden ni lógica performática. Solo la motivación de saber que perderán su dinero, motiva la caótica coreografía. El plano general encuadra, 
en la escena del banco, a la multitud que está ad portas de explotar. La multitud amorfa no se engaña, sale de su convencimiento de que todo está bien y deja de creer el relato institucional, se desmarca y su devenir político busca ocupar la escena. Sin embargo, los protagonistas persiguen su propia causa y ambición, desmarcándose de la protesta general.

En cambio, el malestar e incomodidad de Space Invaders de Nona Fernández (2013), erige una arista diferente. La novela pone de manifiesto la disposición colectiva de la comunidad adolescente, primero, asumiendo el reparto de lo sensible, el lugar asignado al espacio escolar, para luego cuestionar ese reparto desde la marcha política callejera. La organización colectiva de los cuerpos escolares están dispuestos pulcramente en espacio de la escuela, según las disposiciones disciplinarias de esta: "NOS HAN ORDENADO uno delante del otro en una larga fila en medio del patio del liceo. A nuestro lado, otra larga fila, y otra más allá. Formamos un cuadrado perfecto, una especie de tablero. Somos las piezas de un juego, pero no sabemos cuál" (p. 17). Imagen similar a la de Ciencias morales de Martín Kohan, cuando los alumnos cantan el himno nacional en el patio del colegio en plena dictadura argentina, al igual que en La historia oficial (1985) de Luis Puenzo. Este tipo de adoctrinamiento basado en símbolos patrios es común a todas las dictaduras latinoamericanas. En este contexto surge una marcha autogestionada, colectiva y organizada: "Llevamos panfletos en nuestros bolsones" (p. 41), "una gran marcha contra Pinochet, algo nunca visto, algo nunca hecho, algo muy importante" (p. 42), versa el fragmento desde una ingenuidad escolar. El panfleto puede ser visto como materialidad cuyo tratamiento de la letra lo articula como imagen.

Los escolares encuentran en el colegio el espacio del reparto asignado, sin embargo, en la ciudad encuentran otro espacio, el del desborde: "NUNCA LO HABÍAMOS HECHO, pero lo hicimos. Cruzamos la reja del liceo y salimos en manada. Avanzamos uno delante del otro, en una larga fila, pero esta vez no vamos a nuestra sala de clases, vamos a la calle" (Fernández, p. 52). Cruzar la reja es cruzar la frontera, como La Loca en Lemebel, aunque ahora en conjunto, pasan de ser la coreografía aprendida de memoria, pero que desconocen -"Somos la gran pieza de un juego, pero todavía no sabemos cuál" (p. 53)-, a ser la multitud que reprueba el orden establecido, aunque sea de modo ingenuo. Al marchar dejan atrás el liceo, se entregan y pierden en la ciudad (p. 52), abriéndose camino, alertas a todo lo nuevo y extraño que deben enfrentar. Se abren paso en el extravío, con un habla que no les pertenece, que se desvincula del habla aprendida en el colegio, pero que deviene en un aprendizaje incipiente: "Alguien grita algo y alguien lo repite. Otro alguien grita lo mismo y un montón de otros lo repiten. Gritamos lo que se grita. No 
entendemos bien de qué se trata, pero lo hacemos. Aullamos un alarido que sale más allá de nuestras bocas, una consigna inventada y convocada por otros, pero hecha para nosotros" (p. 53). La no comprensión de lo que se enuncia implica avanzar hacia el aprendizaje, un "alarido" animal, que anuncia un camino propio. El estar atentos es un síntoma de lucidez frente a su entorno.

Las dos novelas y la película configuran un sujeto que entra y/o sale del relato colectivo de la multitud, cruza los límites desafiando a la autoridad, disiente de la multitud erigiendo su propio relato, configura un aprendizaje adolescente en el tránsito del conjunto.

\subsection{Comunidad y multitud desideologizada}

Quien deja la comunidad o multitud descree de ella al no formar parte de su cauce. Al acostarse Federico, en El grito de Florencia Abbate (2010), imagina algunos cambios personales que va a enfrentar, lo que de algún modo lo abruma: "Fue por ese motivo que no llegué a oír las caravanas de gente que esa noche se movilizó a la plaza, ni me enteré tampoco por la tele que a la tarde se había decretado el estado de sitio. Jamás hubiera podido suponer lo que me depararía el nuevo día" (p. 31). Marcie Schwartz lee esta novela a partir de la negación de Federico "a participar en cualquier actividad política como reacción al activismo de su madre, el que considera desactualizado. Sin embargo, se encuentra inesperadamente en el centro de un drama callejero la mañana después de los cacerolazos" (p. 18). El 20 de diciembre, día de su cumpleaños, va a inscribirse a un gimnasio, al salir percibe un "clima enrarecido en la cuadra" (p. 32), "calles inquietas", piensa tal vez "era un día de paro general y yo no lo sabía" (Abbate. p. 32). Al cruzar Avenida de Mayo, ve un teléfono público incendiado y "un grupito de pibes que avanzaban gritando "Que se vayan"” (p. 32). Ve a una señora "sacando cacerolas de una bolsa", "una chica que corría con limones en la mano" y un "flaco en moto, a velocidad de rayo, envuelto en una bandera argentina" (p. 33). Llega al gimnasio, le avisan que no puede entrar. Federico avanza a contracorriente de la multitud: "Enjambres de personas huían de la policía, retrocedían para reagruparse y volver a avanzar hacia la casa de gobierno. Yo corrí como un condenado y logré llegar a calle Perón" (p. 44). Federico no asume la escena, de algún modo, intenta desmarcarse de esta, pero la escena lo acecha.

En una escena menos acechante, El bonaerense de Pablo Trapero (2002)

muestra al Zapa llegando a Buenos Aires para convertirse en policía. En su 
tránsito deambulante se cruza con una gran marcha nacional de piqueteros ${ }^{11}$, una gran puesta en escena que atraviesa la cotidianidad de la urbe. Sin embargo, no se interesa por el clamor popular y la atraviesa. La marcha queda atrás y su tránsito nimio continúa. Sin asumir una pose crítica ni incómoda, pasa. Si el protagonista de El bonaerense atraviesa la escena de la protesta, la protagonista de Silvia Prieto de Martín Rejtman (1999) hace una suerte de antiprotesta, pasiva, casi por inercia, en la que los cuerpos agrupados parecieran esperar algo ajeno a lo colectivo más que levantar una exigencia. Se rompe, así, la clásica forma de protesta y de organización sesentera, pues estos tránsitos se desmarcan del tono político que existía en los años sesenta y setenta y tensionan el lugar del gesto de protesta.

En tanto, otra forma de plantear la marcha política desmarcada, es la protesta que rememora Machuca de Andrés Wood (2004), la cual pone en escena la polarización de derecha e izquierda y la mercantilización de este tipo de manifestación. Se cotejan la marcha de la izquierda y la de la derecha, intersectadas -desde un lugar neutro y desideologizado- por el vendedor de banderitas, que perteneciendo a una ideología de izquierda no tiene problemas en vender sus mercancías en ambas manifestaciones. Andrés Wood propone una película en la que se rememora -con nostalgia-el discurso social y político de los setenta, quebrado por la dictadura militar, sin embargo, se desmarca de ese tono al poner de manifiesto la ambigüedad del vendedor, que se puede leer desde una lógica marxista -el sujeto proletario debe trabajar y produciry desde una lógica pretransicional de la Concertación, con cierta comodidad como administración neoliberal. La multitud es una masa homogénea, ambas marchas se parecen en la medida en que convergen desde su polarización.

Las tres formas propuestas en este punto apuestan por una retórica de los cuerpos desinteresada por el relato colectivo. Se tiende a evadir o atravesar la multitud o abandonar el relato colectivo, desde la desidia o desde las normas del mercado, que permiten asumir al cliente protestante, sea de izquierda o derecha.

\subsection{Desarticulaciones de la comunidad y la multitud}

El punto anterior da cuenta de ciertas distancias con la comunidad organizada, pero sin un discurso del todo crítico ni lúcido. La lógica de

\footnotetext{
"Gonzalo Aguilar sostiene que es como si "se hubiese encontrado con un fragmento de La hora de los hornos o de Memoria de un saqueo, de Fernando Pino Solanas" (Otros Mundos. Un ensayo sobre el nuevo cine argentino, p. 198).
} 
construcción de escenas de Los topos de Félix Bruzzone (2008) se basa en las formas de articular o desarticular un presente y pasado político, mediante la ironía de la presencia militante de HIJOS y su parodia con posibles grupos como SOBRINOS o NUERAS (p. 18). En el contexto de este gesto, que cuestiona la memoria colectiva y descree de la comunidad, surge la marcha: "Frente al Congreso había gente con bombos y banderas. No era una marcha de orgullo gay, tampoco de jubilados. El cartel de HIJOS podía verse dos cuadras antes, el viento lo embolsaba y parecía que se iba a caer pero no, estaba bien sujeto" (p. 48-9). La marcha es secundaria en el relato, la aparente caída del cartel es irónica. Es parte de la escena citadina del narrador que sigue los pasos de Maira, la travesti que planifica asesinar a represores. No hay nostalgia respecto de la marcha ni de sus propósitos. A diferencia, por ejemplo, de la novela de Díaz Eterovic, que asume la funa como ejercicio político comprometido. Pareciera que los topos solo buscan el subsuelo, no la escena performática pública.

Otro ejercicio de distancia crítica es que realizan Bettina Perut e Iván Osnovikoff (2011) en La muerte de Pinochet, articulando un discurso paródico a contrapelo de la enunciación que hace multitud en medio de la celebración improvisada de la muerte de Pinochet. El documental muestra a cuatro personajes: dos seguidores de Pinochet -en la línea de I love Pinochet de Marcela Said (2001)-; un socialista comprometido políticamente, que termina disfrazado de viejo pascuero, y un alcohólico que se pierde en medio de la muchedumbre. Personajes que se vinculan con la multitud, pero que desde la mirada del documental son desvinculados o "extirpados" (Corro, 2012, p. 230) de la escena fúnebre. El registro visual de la espera de los simpatizantes de Pinochet da cuenta de un tiempo muerto, los asistentes cantan "El rey" y su performatividad es apagada, son cuerpos pasivos. Las imágenes están marcadas por el canto -también del Himno Nacional-, el rezo y por el grito: "Comunistas, maricones, le mataron los parientes por hueones" (min. 11.15). Los adherentes de Pinochet funcionan en su performatividad apagada como actores y espectadores no emancipados, en tanto asumen el lugar pasivo del espectador ${ }^{12}$. En ese contexto, surgen las voces de los dos adherentes protagonistas, cuyo discurso fanático se articula con la imagen -el enunciado mayestático propuesto por Aguilar- que se deforma en su propia enunciación $\mathrm{y}$, sobre todo, en el tratamiento de los rostros que realizan los documentalistas.

\footnotetext{
${ }^{12}$ Para Rancière, la emancipación "comienza cuando se vuelve a cuestionar la oposición entre mirar y actuar, cuando se comprende que las evidencias que estructuran de esa manera las relaciones del decir, del ver y del hacer pertenecen, ellas mismas, a la estructura de dominación y de la sujeción" (El espectador emancipado, p. 19).
} 
Al igual que la comunidad que escenifica su coreografía desbordada y festiva que manifiesta su alegría ante la muerte de Pinochet. Cuerpos y voces que protagonizan la fiesta urbana de celebración en Plaza Italia. Perut y Osnovikoff matizan "planos cerrados a los eufóricos testimonios que deforman el contenido de estos... con planos generales a la multitud" (Valenzuela, 2017, p 61) ${ }^{13}$. Los planos cerrados o los primerísimos primeros planos deforman los rostros, en la intimidad y en medio de la multitud. De algún modo, contravienen la obsesión que Gonzalo Aguilar aprecia en el documental latinoamericano, "que intenta cifrar una historia, una memoria, un espacio, una subjetividad" (Más allá del pueblo, 2016, p. 143) que, en todo caso, difiere de la apuesta y retórica de Perut y Osnovikoff. La coreografía de Aguilar, captada por la pareja de directores, "tanto de quienes lloran como de quienes celebran la muerte de Pinochet, muestra la crisis del colectivo" (Valenzuela, 2017, p. 62). El cine de Perut y Osnovikoff articula el gesto constante de descomposición de los lugares del documental, de los rostros, de los objetos de la multitud.

Por su parte, I love Pinochet de Marcela Said (2001) descompone en testimonios unitarios el fanatismo desbordado por la figura del dictador Augusto Pinochet, preguntándose por quiénes son los pinochetistas. La reunión es interna, los cuerpos comparten espacios de confort. "Chi-chi-chi, le-lele, viva Chile Pinochet" (min. 2.56) gritan sentados en una larga mesa. Una mujer habla en plena calle, con un megáfono, sin ser atendida por quienes pasan, que siguen su rutina. Marcela Said escenifica el fanatismo en el espacio público - sin respuesta del colectivo- y en la intimidad de algunos partidarios. Said acierta con el acercamiento al discurso de los partidarios de Pinochet, proyectándose de manera deformada, pues en el relato expositivo y la distancia que este establece, opera la parodia de dicho discurso. En este documental y en Opus dei, Said logra ingresar a la intimidad de espacios no siempre expuestos públicamente. En I Love Pinochet recurre a imágenes de multitudes políticas de la derecha pinochetista, primero, de la campaña del Sí para el plebiscito de 1988, y, segundo, de la campaña electoral de Joaquín Lavín, "heredero de Pinochet" que estuvo a punto de salir electo presidente.

Tanto los dos documentales como la novela se desmarcan de toda épica colectiva posible. Épica que puede ser rastreada en el documental chileno y argentino de la década de sesenta y setenta, para lo cual resultan relevantes los trabajos de Carlos Ossa y Gonzalo Aguilar. En cambio, los carteles que levantan

\footnotetext{
${ }^{13}$ El plano general remite al cine de los sesenta y es estilizado en Machuca de Andrés Wood (Corro, pp. 72-74), y desarticulado por Perut y Osnovikoff.
} 
los personajes del corpus acá analizado en este punto son frágiles, desde el fundamento que los levanta y tensiona, hasta la ejecución en la escena pública.

\subsection{La multitud y la comunidad fallidas}

Sería interesante hacer un ejercicio inverso y pensar el pre-desmarque en Mano de obra de Diamela Eltit (2005). En la novela se articula una incipiente forma de organización colectiva, sindical, que fracasa antes de gestarse y de salir a la calle. "Alberto tenía malas costumbres" (p. 87), dice el narrador, respecto del personaje que organiza un sindicato. Esa impresión es gestada producto de una lógica neoliberal y de la precarización laboral: "Por eso nosotros no teníamos contrato. Para que jamás se formara un sindicato" (p. 89). Eltit, en esta novela, exacerba el discurso del encierro, tanto en el supermercado como en la casa colectiva. Rubí Carreño sostiene que la ausencia de cualquier forma colectiva - pareja, familia, nación- en Mano de obra da cuenta “de la penetración que el mercado realiza en estos y otros colectivos menos naturalizados" (Memorias del nuevo siglo. Jóvenes, trabajadores y artistas en la novela chilena reciente, p. 94). Los cuerpos no logran abrirse hacia el espacio de la ciudad, no hay posibilidad de un "nosotros, el pueblo" ni tampoco un desmarque ranceriano de poder llegar al hora en la noche y leer. No hay posibilidad de disenso y menos de nostalgia por el discurso político de décadas atrás.

\section{Comentarios finales}

El objetivo de articular una lectura en torno a cómo la comunidad/multitud se vincula y desvincula performáticamente de la escena de la marcha en el corpus chileno y argentino, permite pensar las formas colectivas de articulación o las formas en que ciertos sujetos se relacionan con este en disciplinas diferentes, pero que encuentran ejes representacionales en común. Así, desde ese vínculo se desprenden modos de asumir el espacio público, no tanto desde la nostalgia histórica, sino desde una enunciación, corporal o hablada, que se afirma en proyectos políticos colectivos o duda de estos, situados desde contextos de posdictadura neoliberal, tanto en Chile como en Argentina.

El artículo no plantea un modo único de erigir la marcha o la protesta, y menos de vincularse a esta. Los matices que ofrece permiten pensar una retórica performática que comprende ciertas escenas y cuadros como complejas formas en las que convergen la comunidad, los cuerpos, los espacios e imágenes. Estas últimas, pensadas desde la latencia de la mirada. La funa, por ejemplo, rompe la rutina del espacio citadino en la novela de Díaz Eterovic, en tanto, la 
protesta callejera es acompañada por la ruptura de los límites de la autoridad, por parte de la Loca del Frente de Lemebel. Tales rupturas tensionan el lugar del sujeto o muchedumbre con la autoridad, como sucede en la película de Bielinski. Por su parte, la comunidad adolescente da sus primeros pasos hacia el desmarque político en su marcha hacia la protesta política que expone la novela de Fernández.

Por otra parte, algunos personajes toman distancia de las diversas formas de articular un relato de lo colectivo, como Federico en la novela de Abatte; como el Zapa en la película de Trapero; como Silvia en la de Retjman. Otros juegan a la ambigüedad, al desideologizar el lugar de la protesta desde la lógica mercantil, como en la película de Wood. En tanto, en los ejercicios de Bruzzone, la dupla Perut-Osnovikoff y el documental de Said esa distancia está enfocada hacia los sujetos que marchan, no hay épica en su andar, a diferencia de lo que sucede en los documentales de Pino Solanas y Moreno. Finalmente, Eltit radicaliza el gesto y elimina el espacio público de la posible escena de protesta.

En general, lo relevante es que la idea de retórica performática cuestiona el lugar de la letra (Taylor, p 52), desde una operación que se niega a ser clasificada. La retórica performática, en sí, es dinámica en su lectura y en su espesor político, en síntesis, es asumida desde narrativas literarias y cinematográficas que adoptan ese riesgo o esa intención. Esta negación, sea por desidia, ingenuidad o distancia crítica, permite configurar una representación de un sujeto y de una comunidad desmarcada de los procesos políticos de posdictadura neoliberal.

\section{Referencias}

Abbate, Florencia (2010). El grito. Veracruz: Universidad Veracruzana.

Aguilar, Gonzalo (2016). Más allá del pueblo. Imágenes, indicios y políticas del cine. Buenos Aires: Fondo de Cultura Económica.

Aguilar, Gonzalo (2010). Otros Mundos. Un ensayo sobre el nuevo cine argentino. Buenos Aires: Santiago Arco editor.

Bongers, Wolfgang (2017). Interferencias del archivo. Cortes estéticos y politicos en cine y literatura. Frankfurt: Peter Lang.

Bruzzonne, Félix (2008). Los topos. Buenos Aires: Mondadori. 
Butler, Judith. (2014). "Nosotros, el pueblo". Apuntes sobre la libertad de reunión. ¿Qué es un pueblo? Santiago de Chile: LOM, pp. 41-60.

Carreño, Rubí (2013). Av. Independencia. Literatura, música e ideas de Chile disidente. Santiago de Chile: Editorial Cuarto Propio.

Carreño, Rubí (2009). Memorias del nuevo siglo. Jóvenes, trabajadores y artistas en la novela chilena reciente. Santiago de Chile: Editorial Cuarto Propio.

Castillo, Alejandra (2015). Imagen-cuerpo. Santiago de Chile: Palinodia.

Corro, Pablo (2012). Retóricas del cine chileno. Ensayos con el realismo. Santiago de Chile: Editorial Cuarto Propio.

De Certeau, Michel (2000). La invención de lo cotidiano. México: Univ. Iberoamericana.

Díaz Eterovic, Ramón (2008). La oscura memoria de las armas. Santiago de Chile: LOM.

Didi-Huberman, Georges (2012). Supervivencia de las luciérnagas. Madrid: Abada.

Domínguez, Héctor (2004). "La Yegua de Troya. Pedro Lemebel, los medios y la performance". En F. Blanco (Ed.), Reinas de otro cielo. Modernidad y Autoritarismo en la obra de Pedro Lemebel (pp. 117-149). Santiago de Chile: LOM.

Eltit, Diamela (2005). Mano de obra. Santiago de Chile: Seix Barral.

Fernández, Nona (2013). Space Invaders. Santiago de Chile: Alquimia.

Garcés, Mario (2012). Introducción. El despertar de la sociedad. Los movimientos sociales en América Latina y Chile. Santiago de Chile: LOM, pp. 7-12. 
Grau, Olga (2000). "El encapuchamiento de la memoria". En N. Richard (Ed.), Políticas y estéticas de la memoria (pp. 199-204). Santiago de Chile: Editorial Cuarto Propio.

Hardt, Michel y Negri, Antonio (2008). El Imperio y la multitud: un diálogo sobre el nuevo orden de la globalización. Conversación entre Toni Negri y Danilo Zolo. La multitud y la guerra. Santiago de Chile: LOM.

Lemebel, Pedro (2008). Tengo miedo torero. Santiago de Chile: Seix Barral.

Ossa, Carlos (2013). El ojo mecánico. Santiago de Chile: Fondo de Cultura Económica.

Rancière, Jacques (2010). El espectador emancipado. Buenos Aires: Manantial.

Rancière, Jacques (2011). El destino de las imágenes. Buenos Aires: Prometeo Libros.

Rancière, Jacques (2014). El reparto de lo sensible estética y política. Buenos Aires: Prometeo Libros.

Schwartz, Marcie (2017). "Cacerolazos y bibliotecas: lectura, solidaridad y espacio público después de la crisis Argentina de 2001-2002”. Revista de Humanidades, 35, pp. 15-42.

Tabarowsky, D. (2014). Literatura de izquierda. Santiago de Chile: Calabaza del Diablo-Das Kapital.

Taylor, Damián (2015). El archivo y el repertorio. La memoria cultural performática en las Américas. Santiago de Chile: Ediciones Universidad Alberto Hurtado.

Valenzuela Prado, Luis (2017). "Desespectacularización, cuerpo y muerte. Enlaces y desvinculaciones de la imagen en el cine de Perut y Osnovikoff”. En M. Villarroel, (Coord.), De Ruiz a la utopía contemporánea en el cine chileno y latinoamericano. (pp. 55-64). Santiago de Chile: LOM. 
Valenzuela Prado, Luis (2012). "Transición, memoria y neoliberalismo en la ciudad de La oscura memoria de las armas de Ramón Díaz Eterovic". Contextos, 28, pp. 141-154.

\section{Filmografía}

Bielinsky, F. (2000). Dir. Nueve reinas.

Moreno, S. (2006). Dir. La ciudad de los fotógrafos.

Osnovikoff, I. y B. Perut. (2011). Dir. La muerte de Pinochet.

Rejtman, M. (1999). Dir. Silvia Prieto.

Said, Marcela. (2001). Dir. I love Pinochet.

Solanas, F. (2005). Dir. La dignidad de los nadies.

Trapero, P. (2002). Dir. El bonaerense.

Wood, A. (2004). Dir. Machuca. 